\title{
Digital Mass Media Group Platform in Society Era 5.0
}

\author{
Woro Harkandi Kencana ${ }^{1}$, Meisyanti ${ }^{2}$ \\ \{woro.harkandi@gmail.com¹,meisyanti.hutagaol@gmail.com²\} \\ Universitas Persada Indonesia YAI, Jakarta, Indonesia ${ }^{12}$
}

\begin{abstract}
TransMedia Group is one of the media groups that carry out the stages of communication technology in disseminating information. This study wants to find out how the implementation of the digital platform carried out by the TransMedia Group as mass media in facing the competition in the media industry in Indonesia. This study uses the perspective of The Communication Technology Ecosystem in conducting its analysis with a qualitative approach and data collection techniques using interviews and observations of the management and digital group platform. The results of this study, the TransMedia communication technology ecosystem uses hardware in the form of a device platform while the software is in the form of websites, social media, and applications. The content on this digital platform is in the form of text, video, and audio information that is integrated between media in the TransMedia Group in its organizational infrastructure. Media convergence is a form of implementing digital platforms in media groups using digital platforms not only in the form of hardware but also in changing the mass media organizational system and the interaction that exists with the audience to become more interactive.
\end{abstract}

Keywords: digital platform, The Communication Technology Ecosystem

\section{Introduction}

Advances in technology have made the development of the communication industry in Indonesia undergo many changes including mass media. This digital technology supports new interactions between audiences and the media as well as between audiences and other audiences. Currently, mass media technology in Indonesia is moving towards society 5.0. According to Fukuyama (2018), Japan is promoting Society 5.0 by introducing digital technologies in a variety of systems, well as accelerating its implementation to achieve a society in which all citizens are dynamically engaged. The goal of Society 5.0 is to realize a society where people enjoy life to the fullest. Economic growth and technological development exist for that purpose, and not for the prosperity of a select few [1]. The communication industry in Indonesia, especially the big media groups, has entered society 5.0. Implementation through digital platforms allows the public to engage in dynamic information dissemination.

Feld (2019) define a digital platform as (1) A service accessed via the internet; (2) the service is two-sided or multisided, with at least one side open to the public that allows the public to play multiple roles (e.g., content creator as well as content consumer); and (3) which therefore enjoys particular types of powerful network effects [2]. Digital platforms and conventional platforms converge by major media groups in Indonesia. On conventional platforms, there are forms of television, radio, and newspapers, while digital platforms 
include online media, websites, social media to applications. Research by Tapsell (2015) The term convergence is of course not new, but through the digitalization of media entities, which were previously specialized, the future of media in Indonesia is large multiplatform news providers. This has numerous implications for media freedom, including an increased concentration of ownership [3]. As an idea, convergence can benefit the industry because it integrates all channels so that their loyal viewers can get news from the same media company through different channels. With the increasing number of media operators, there is intense competition for the attention of the public. Each media group will strive to gain public attention through the use of several channels. The more channels they have, the more attention they get from the public [4].

Currently, the major media groups in Indonesia are TransMedia Group, MNN group, Media Group, Kompas Group, Jawa Post Group, Emtek, Mahaka Group, and Berita Satu Holding. In this study, the unit of analysis focused on one group, namely the TransMedia Group. Under the auspices of PT Trans Media Corpora and under the core business of the CT Group which is owned by Indonesian conglomerate Chairul Tanjung. This media group owns Trans TV, Trans7, detik.com, CNN, CNBC, HaiBunda.com, and InsertLive.com. There are only two conventional platforms Trans TV and Trans7 in the media, but entering the media competition in the realm of digital technology is also owned by the two televisions.

In this research, the perspective used is the "Technology Ecosystem" by August E Grant. The core of the technology ecosystem consists of hardware, software, and content (as previously defined). Surrounding this core is the organizational in- infrastructure: the group of organizations involved in the production and distribution of the technology. The next level moving outwards is the system level, including the political, economic, and media systems, as well as other groups of individuals or organizations serving a common set of functions in society. Finally, the individual users of the technology cut across all of the other areas, providing a focus for understanding each one. The basic premise of the technology ecosystem is that all areas of the ecosystem interact and must be examined to understand a technology [5].

Previous research has been conducted by W.H.Kencana (2014) entitled Media Convergence in the Institutional Analysis of TransMedia Group Business Communications. Its institutional policy TransMedia Group carries out media convergence in the face of increasingly fierce competition in the media industry. This media competition cannot be avoided during a free market that is competing for the market, advertising revenue, and investors. Media convergence is the right policy to integrate systems within institutions from a technological and professional management perspective. The form of convergence that occurs in the TransMedia Group is technology convergence, economic convergence, and content convergence, while the convergence stages that have been carried out are crosspromotion, cloning, competition, and content sharing at the stage of convergence. full convergence even though TransMedia does not yet have a joint newsroom (single newsroom/production room). Business communication supports the convergence of media with the right organizational culture and leadership so that media groups will strengthen the existence of institutions during free markets in the regional and international [6].

Based on research by García-Avilés (2009), research was conducted in six media companies that are undergoing some degree of newsroom convergence in Austria, Spain, and Germany. Descriptors for different levels of cross-media production and the process of convergence were established avoiding technological determinism and the typical mindset in the industry that regards full integration as the necessary final step of any convergence project. three models of newsroom convergence were drawn: full integration, cross-media, 
and co-ordination of isolated platforms. [7]. TransMedia uses a cross-media model where they do not use a shared newsroom but exchange content to meet the needs of the news on the platform. In his continued research in the digital era, García-Avilés (2014) emphasizes that audience participation is becoming a key strategic question in all newsroom models, whereas the traditional logic and rhythms of daily newspaper production are losing ground [8].

Currently, TransMedia Group has entered the Society 5.0 era, the development of digital platforms is increasingly competitive among media groups. This research wants to know how the implementation of the digital platform carried out by the TransMedia group as mass media in the era of society 5.0 .

\section{Research Method}

This research uses a descriptive qualitative approach. In research with a qualitative approach, the data is based on the field, which means that the way to obtain it is based on 'field' sources. The sources of this "field" are in the form of persons/individuals who are the research subjects. They exist during society, either as independent individuals or as part of a particular community [9]. The data collection technique was carried out with primary data types in the form of interviews conducted at Mujahid Hanifah Head of Section Marketing Digital Content Creative Trans TV and observations on the media group through literature studies, media coverage, and accounts of the TransMedia group digital platform. The object of research is the implementation of the digital platform used by the TransMedia group while the research unit is the TransMedia Group which has various forms of mass media, namely: free to air television, subscription television, subscription channels, online media, and other digital applications.

The data analysis technique used in this study uses steps as stated by Miles and Huberman cited by Sugiyono (2010), namely: data reduction, data presentation, and drawing conclusions or verification. This study was analyzed at each stage in the process, carried out to obtain the validity of the data, namely by examining all existing data from various sources obtained from the field, pictures, photos, etc. through observation methods supported by literature and documentation studies [10].

\section{Results and Discussion}

\subsection{The Communication Technology Ecosystem: In TransMedia Group}

The hardware, software, and content must also be studied within a larger context. Rogers' (1986) definition of "communication technology" includes some of these contextual factors, defining it as "the hardware equipment, organizational structures, and social values by which individuals collect, process, and exchange information with other individuals" (p. 2). An even broader range of factors is suggested by Ball- Rokeach (1985) in her media system dependency theory, which suggests that communication media can be understood by analyzing dependency relations within and across levels of analysis, including the individual, organizational, and system levels. Within the system, These two approaches have been synthesized into the "Technology Ecosystem" illustrated in Figure 1 [5]. 


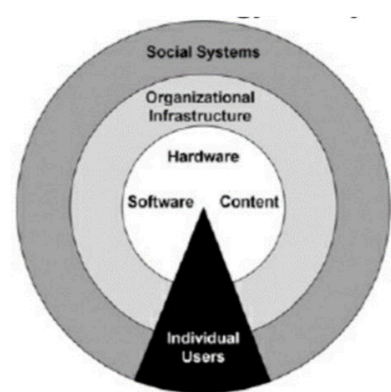

Fig 1. The Communication Technology Ecosystem

In this study, the implementation of the TransMedia Group digital platform in the Technology Ecosystem consists of hardware, the hardware used in the digital platform is the production tool used in the form of computer devices, handheld telephones, and production equipment and equipment in transmission. Software on a digital platform is a form of website, online media, applications, and social media. It can be seen from the table below.

Table 1. TransMedia Group digital platform

\begin{tabular}{|c|c|c|c|c|c|}
\hline $\begin{array}{l}\text { Media } \\
\text { Name }\end{array}$ & Media Forms & Online TV website & $\begin{array}{l}\text { Digital Platform } \\
\text { Online media }\end{array}$ & Application & $\begin{array}{l}\text { Social } \\
\text { media }\end{array}$ \\
\hline $\begin{array}{l}\text { Trans } \\
\text { TV }\end{array}$ & FTA* & www.TransTV.co.id & - & Trans Tv Live & $\begin{array}{l}\text { have } \\
\text { accounts on }\end{array}$ \\
\hline Trans7 & FTA* & www.Trans7.co.id & - & & social \\
\hline $\mathrm{CNN}$ & TV Channel & - & www.cnnindonesia.com & CNN Indonesia & media: \\
\hline $\mathrm{CNBC}$ & TV Channel & - & www.cnbcindonesia.com & $\begin{array}{l}\text { CBNC } \\
\text { Indonesia }\end{array}$ & $\begin{array}{l}\text { Facebook, } \\
\text { Instagram, }\end{array}$ \\
\hline Detik & Online Media & - & www.detik.com & $\begin{array}{l}\text { Detikcom, } \\
\text { 20DETIK dan } \\
\text { PasangMata }\end{array}$ & $\begin{array}{l}\text { Twitter, } \\
\text { and } \\
\text { Youtube }\end{array}$ \\
\hline $\begin{array}{l}\text { Hai } \\
\text { Bunda }\end{array}$ & Online Media & - & $\underline{\text { www.HaiBunda.com }}$ & HaiBunda & \\
\hline $\begin{array}{l}\text { Insert } \\
\text { Live }\end{array}$ & Online Media & - & www.InsertLive.com & Insertlive & \\
\hline $\begin{array}{l}\text { Transv } \\
\text { ision }\end{array}$ & $\begin{array}{l}\text { Subscription } \\
\text { TV }\end{array}$ & www.transvision.co.id & - & Transvision & \\
\hline
\end{tabular}

*Free to Air (FTA)

For the website, TransMedia Group has a website for free to air television media, news portals, and television channels. The FTA television website, namely: www.TransTV.co.id and www.Trans7.co.id then these two terrestrial televisions have a joint application, namely Trans TV Live, while for the news and entertainment division there are online media www.detik.com, www.cnnindonesia.com, www.cnbcindonesia.com, www.HaiBunda.com, and www.InsertLive.com. The application form owned by detikcom is incorporated in it for 20 seconds andasangMata, CNN Indonesia, CNBC Indonesia, Insert Live, Haibunda, and Transvision on the play store. As for social media, each TransMedia Group media network has social media accounts on Facebook, Instagram, Twitter, and Youtube channels. For television stations, each broadcast program also has a Facebook, Instagram, and Twitter account.

Next is the content, on the television website providing information about the programs in the FTA Trans Tv and Trans7 including their live streaming shows. The content on this television broadcasts entertainment and news programs. Apart from the online television 
website, broadcasts can also be watched on Trans TV Live. Detikcom is a web portal that contains news and online articles in Indonesia. For the 20Detik application is a form of news video from detikcom which is presented briefly for only 20 seconds whileasangMata is a media citizen journalism from detikcom where the news presented is in the form of images and videos from the public on the choice of the detikcom editor.

Cable News Network (CNN) Indonesia is a digital news television station and pays on its digital platform presenting the latest news in the form of online media and applications. Consumer News and Business Channel Indonesia (abbreviated CNBC Indonesia) is a television station and news site Broadcasting in Bahasa Indonesia, CNBC Indonesia's channel provides national and international content, with a focus on business, finance, stock exchange capital markets, and the economy. Haibunda.com is here as an online mass media that provides information about the world of parenting, pregnancy, breastfeeding, the life of a mother, both from experts and experiences of other mothers. Present to provide information about celebrity life and other entertainment in digital format through insertlive.com. The social aspect that is viral in the community is also one of Insertlive's interesting content which is not only presented in the form of text, photos, videos, but also infographics and 24hour streaming.
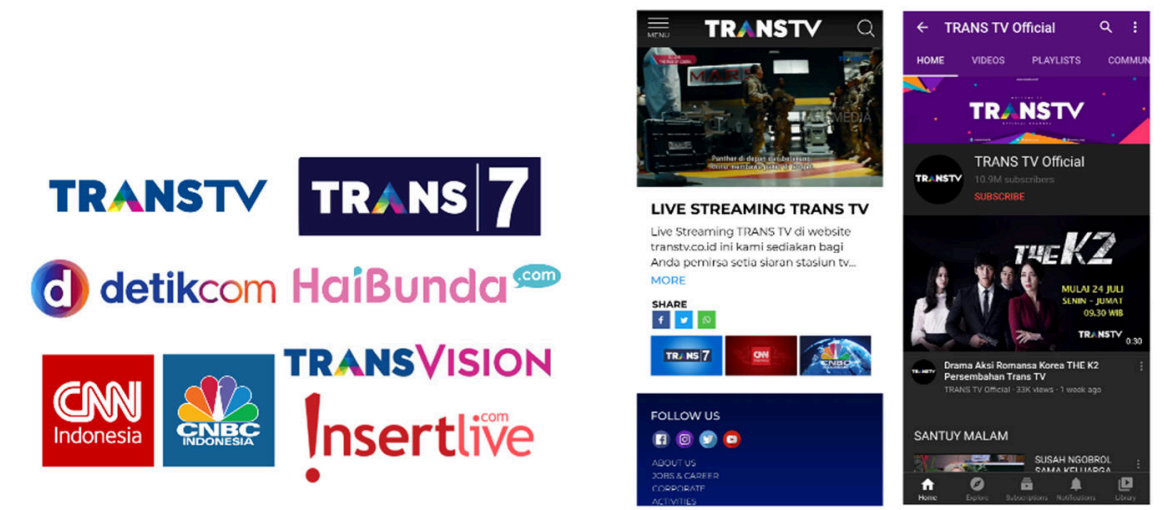

Fig 2. TransMedia Group

Based on the results of an interview with Mujahid Hanifah Head of Section Marketing for Digital Content Creative Trans TV, explaining the distribution of content on the digital platform Transmedia:

“... konsumsi media program terutama program di televisi itu sangat tinggi di youtube. Jadi kita beda-beda, kalau Trans TV dan Trans 7 lebih banyak bermain di Facebook, YouTube Twitter dan Instagram untuk platformnya. tapi kalau untuk CNN, CNBC sama detik itu beda lagi. CNN dia juga bermain di Youtube Tapi kalau di dalam persentase $30 \%$ bermain di YouTube $70 \%$ lebih banyak main website karena dia ada website basednya ada cnnindonesia.com portal beritanya itu ada. CNBC juga hampir sama, $80 \%$ lebih menggunakan platform yang tadi cnbcindonesia.com dan bukan di platform yang lain, kalau detik dia bermain di YouTube Itu cuma 10\% mungkin tidak terlalu banyak main di sana, karena dia lebih memilih menggunakan platformnya."

“... consumption of program media, especially television programs, is very high on YouTube. So we are different if Trans TV and Trans 7 play more on Facebook, YouTube, Twitter, and Instagram for their platforms. but for CNN, CNBC, and the second it's different again. CNN also plays on Youtube But if the percentage of $30 \%$ plays on YouTube $70 \%$ play 
more websites because he has a website based on cnnindonesia.com the news portal is there. $C N B C$ is also almost the same, $80 \%$ prefer to use the previous platform cnbcindonesia.com and not other platforms, if the second he plays on YouTube it's only 10\% maybe he doesn't play too much there, because he prefers to use the platform."

The use of the digital platform made by TransMedia maximizes the digital media website, the Trans Live application for streaming, and social media including Youtube, Facebook, Instagram, and Twitter. Currently, the strategy for television content trends is to collaborate with Youtube channels that have been managed by none other than television artists themselves, for example, Ruben Onsu, Baim Wong, and Rafi Ahmad. Next in The Communication Technology Ecosystem chart that surrounds this core is the organizational infrastructure which is a group of organizations involved in the production and distribution of technology. TransMedia Group is a media company under Chairul Tanjung's CT group. For FTA television currently, Trans7 still has shared from Kompas Gramedia, while Trans TV is full ownership of TransMedia.

Other television platforms are $\mathrm{CNN}$ and $\mathrm{CNBC}$ Indonesia, these platforms are digital and pay television channels. Cable News Network (CNN) Indonesia is a news site owned by Trans Media in collaboration with WarnerMedia, a division of AT\&T. Meanwhile, Consumer News and Business Channel Indonesia (abbreviated as CNBC Indonesia) is a television station and business news site owned by Trans Media in collaboration with NBC Universal, a division of Comcast. For online media and applications, PT Trans Digital Media is currently under direct supervision. Meanwhile, Transvision subscription television, which previously owned by Telkom as a state-owned company, is now fully owned by TransMedia.

In this media organization, TransMedia performs media convergence, the convergence that they do enter the realm of digital platform implementation. In terms of content, this group shares information between media even though they have not used the same newsroom. For TransTV at this time they no longer have a news division. Convergence is carried out by broadcasting CNNIndonesia news broadcasts on TransTV as its news program. In the technology convention between media, this group uses the same tools and even the same applications such as live streaming and video on demand on the Trans Live application used by Trans TV and Trans7. As well as a convergence for cross-promotion programs.

The next level that moves outside is the system level, including the political, economic, and media systems, as well as groups of individuals or other organizations that serve a series of common functions in society. Entering society 5.0 competition between media is increasing with the various media platforms offered. Competition is not only in finding audiences but the portion of advertisements which is the main source of income for mass media institutions in Indonesia. When a mass media institution has shifted into an industry, profit becomes a top priority in the survival of a media's operations. In a competitive climate, a monopoly can occur. This monopoly atmosphere can occur due to the tough competition system so that strong economic players are needed.

Media monopoly can take several forms: 1) Duopoly: an economic system that can also apply in the media when there are only two main players who control and dominate $50 \%$ of the market. 2) Oligopoly: an economic system that can also apply in the media industry when several industries control and dominate $30 \%$ of the market. And 3) Monopoly: an economic system that shows one industrial player who dominates and controls almost $90 \%$ of the market (Graham in McQuail, 2000)[11]. Currently, the existence of TransMedia as part of a 
media industry together with other large media groups has made the atmosphere of media competition enter into an oligopoly.

Individual users in the communication technology ecosystem become the foundation in fulfilling the need for information through digital platforms. According to We are social Digital 2020 data, it is noted that active users of social media in Indonesia reach 160 million with a penetration of 59 percent of the total population. This number is up 8.1 percent or around 12 million users. The time an average Indonesian spends on social media is three hours and four minutes. Almost all internet users in Indonesia, or 99 percent of them, also like to watch online videos. From this data, TransMedia makes maximum use of digital platforms in the form of social media and video streaming applications. Over the past years, social media logic has gradually infiltrated mass media logic, sometimes enhancing it, undercutting, or replacing parts of it (Dijck\&Poell,2013) [12].

This was explained by Mujahid Hanifah Head of Section Marketing Digital Content Creative Trans TV:

"kita tinggi, kalau di youtube kita peringkat kedua televisi terbanyak kalau Trans TV, kalau Trans 7 peringkat 1. Jadi kita kalo memang untuk penontonnya di digital itu tinggi kok, di website kalau di data terakhir saya perbulannya itu di sekitar 300 ribu unit visitors, trus di facebooknya juga kita lagi growth tinggi banget."

"We are high, on YouTube, we have the second-highest ranking for television, Trans TV if Trans 7 is in 1 . So, if the audience in digital is high, on the website, in my latest data, there are around 300 thousand unit visitors per month. then on Facebook, we are also growing high."

The digital platform becomes an individual user consuming media with a double screen, combining the use of conventional and digital platforms. Today's society needs a digital role in building interactions between other communities and also the media. The use of digital platforms makes people realize people who can enjoy life.

\subsection{Media Convergence As a Form of Digital Platform Implementation}

The use of digital platforms in mass media is in line with developments in communication technology. According to (Skobelev \& Borovik, 2017) The provided review shows that the growing popularity of the digital economy and the uncountable number of practical applications have created a strong basis for the development of Industry 4.0 technologies already now and in the long term can serve as the launchpad for creation of Society 5.0. [13]. The emergence of globalizing digital communications platforms followed the intersection of two major global trends in media policy, which shaped the early development and corporatization of the Internet ( Flew.et.al,2019)[14]

The perspective of the Communication Technology Ecosystem in the TransMedia group is also passed by other media groups. The stages in this perspective are a media system that survives media competition, not only conventional media but also competition in the digital realm. According to Adoni \& Nossek (2004), The present media environment is a complex system of interconnected components, and any change, such as the addition of a new component, or convergence between two or more components, will lead to a change in the reciprocal relationships between them all. Furthermore, changes in the media environment, including production, distribution, and consumption patterns, are found to develop under particular social conditions and cultural climates[15].

The era of new media in the form of digital platforms brings new sources of complexity and uncertainty. The convergence of the media is driving this evolution, and the changes will prove deep and permanent. Many observers in the media industry are pessimistic about these 
changes and their impact on the media business model. However, evidence suggests that the media industry can also accept this evolution, as many opportunities arise from the evolving media business model (Philips \& Merlo, 2008).[16] This complexity and uncertainty are due to the very fast development of digital platforms, so media owners must be able to accurately read these developments in gaining an audience.

Based on Helfat and Raubitschek's (2018) theoretical analysis research which explains the ways dynamic capabilities support not only value creation but also value capture by platform leaders. According to the research, three types of dynamic capabilities are at least very important for platform leaders: innovation capabilities, environmental scanning and sensing capabilities, and integrative capabilities for ecosystem orchestration. They further argue that integrative abilities play a key role in enhancing platform leaders' ability to capture value[17].

Media convergence is the merging or integration of existing media to be used and directed into a single destination. Media convergence usually refers to the development of digital communication technology made possible by network convergence. The implementation of the digital platform is a form of convergence carried out by mass media groups. Based on the results of the research of the Transmedia groups which are the objects of research on the forms of media platforms that are owned in the integrated media group. It can be seen clearly in the form of media journalism, the integration that occurs between television journalism, print, and online media. Processes of media convergence are neither new nor exclusive to the Internet: Many leaps in media technologies over the years have led to the integration of formerly distinct media products and functions. However, the pervasive nature of the current shift, as well as the maturation of journalism studies as a field of inquiry, means that digital media have been scrutinized extensively and intensively throughout their development. For scholars, the result has been something of a paradigm shift, with rapidly evolving frames of reference and objects of observation. For journalists who until very recently produced content for a single media product that they alone controlled and to which they alone contributed, ongoing changes have meant new outlets, production structures, and work rules (Quant \& Jane,2009)[18].

Various mergers and acquisitions between media and communications companies are presented to the authorities, the press and shareholders, to generate economic value through the realization of synergies. This rather loose concept covers a wide variety of case scenarios depending on a particular sector, industry, or company. However, from a more theoretical point of view, the realization of synergies through conglomeration generally includes the following five objectives (Flew, 2011; Ozanich \& Wirth, 2004): diversification (i.e., spreading risks and opportunities across different industries and markets), reusing media content through multiple platforms, cross-promotion of cross-platform media content, branding and exploitation of subsidiary rights[19]. At the TransMedia group, mergers and acquisitions provide economic value when these media companies converge. Trans Tv, which previously had a news division, eliminated this division by including news content from their contested channels, namely CNN and CNBC.

Digital platforms also provide two-way communication facilities between media and audiences. According to Ytreberg (2009) in the Pop Idol and Big Brother television program, combining broadcasting with digital platforms is the right strategy. Audience participation through such digital platforms invites a sense of presence, enhances immediacy and involvement in live events. The article emphasizes how these features were developed by the broadcast media industry to exploit audience participation for revenue, competitive advantage, and strategic expansion purposes.[20] 
Increasingly advanced digitalization and media convergence require the TransMedia group to adapt its content to various platforms and distribution channels. The Internet, as a convergent carrier medium, is increasingly taking on a central role as an additional medium. Classic linear TV is still important, but for some viewers, it has evolved from primary to secondary media. Because the biggest challenge for users is finding their way in the huge selection of channels and platforms available. Because in the digital age, First, media content and services are proliferating so rapidly that the volume of material is unlimited. Second, media, both old and new, is increasingly available on-demand via integrated digital networks that allow users to move easily from one thing to the next. Third, the large amount of media consumption by the community makes the community play a role in providing content "(Webster, 2014)[21]. The use of digital platforms in the mass media is not only a technical change but also changes in the system and community involvement which is increasingly active in interacting with the media so that they can produce shared content.

\section{Conclusions}

The implementation of digital platforms in the mass media, especially the TransMedia group, has entered society 5.0 where people use digital technology. Mass media today is not only in conventional form through print, radio, and television screens. The implementation of the digital platform in The Communication Technology Ecosystem has made it easier for people to obtain information and makes it easier for people to interact in communication not only between the media and the audience but also the audience and audience. At the hardware stage, the development of communication devices always develops features including features in software. Platforms that become market demand in obtaining digital information in this group are social media with Facebook, Instagram, and YouTube channels and the Trans Live application.

As well as content on news portal websites that not only present text but also video form. Media convergence is a form of implementing digital platforms in media groups using digital platforms not only in the form of hardware but also in changing the mass media organizational system and the interaction that exists with the audience to become more interactive. The researcher would like to thank Kementerian Riset dan Teknologi / Badan Riset dan Inovasi Nasional (RISTEK-BRIN) Republik Indonesia who has given fund to this research.

\section{References}

[1] M. Fukuyama, "Society 5.0: Aiming for a New Human-centered Society," Japan Spotlight, vol. 27 , no. Society 5.0, pp. 47-50, 2018.

[2] H. Feld, "The Case for the Digital Platform Act: Market Structure and Regulation of Digital Platforms," 2019.

[3] R. Tapsell, "Platform convergence in Indonesia: Challenges and opportunities for media freedom,” Convergence, vol. 21, no. 2, pp. 182-197, 2015, doi: 10.1177/1354856514531527.

[4] Y. Nugroho, D. A. Putri, and S. Laksmi, "Memetakan Lanskap Industri Media Kontemporer di Indonesia (Edisi Bahasa Indonesia)," CIPG dan HIVOS, pp. 1-184, 2012.

[5] J. H. M. August E Grant, "Communication Technology Update And Fundamentals", 16th ed., no. 1. New York: Routledge, 2018.

[6] W. H. Kencana, "Konvergensi Media ( Analisis Institusional Komunikasi Bisnis Pada Transmedia Group )," Gelanggang, vol. i no.1, pp. 1-15, 2014, [Online]. Available: http://karyailmiah.upi-yai.ac.id/index.php?r=view-article\&id=806.

[7] J. A. García Avilés, K. Meier, A. Kaltenbrunner, M. Carvajal, and D. Kraus, "Newsroom 
integration in Austria, Spain, and Germany: Models of media convergence,” Journal. Pract., vol. 3, no. 3, pp. 285-303, 2009, doi: 10.1080/17512780902798638.

[8] J. A. García-Avilés, A. Kaltenbrunner, and K. Meier, "Media Convergence Revisited," Journal. Pract., vol. 8, no. 5, pp. 573-584, Sep. 2014, doi: 10.1080/17512786.2014.885678

[9] Imran, Ali , "Penelitian Komunikasi Pendekatan Kualitatif Berbasis Teks Communication Research Of Text-Based Qualitative Approach."

[10] Sugiyono, Metode Penelitian Kuantitatif Kualitatif dan R\&D. CV.Alfabeta, 2010.

[11] V. A. Lenggawa, "Strategi Jawa Pos Dalam Menghadapi Persaingan," Konvergensi, vol. 01, no. 01, pp. 19-38, 2019.

[12] J. van Dijck and T. Poell, "Understanding social media logic," Media Commun., vol. 1, no. 1, pp. $2-14,2013$, doi: $10.12924 / \operatorname{mac} 2013.01010002$.

[13] Skobelev and Borovik, "On The Way From Industry 4.0 to Industry 5.0: From Digital Manufacturing to Digital Society," Int. Sci. J. "Industry 4.0,” vol. II, no. 6, pp. 307-311, 2017.

[14] T. Flew, F. Martin, and N. Suzor, "Internet regulation as media policy: Rethinking the question of digital communication platform governance," J. Digit. Media Policy, vol. 10, no. 1, pp. 33-50, Mar. 2019, doi: 10.1386/jdmp.10.1.33_1.

[15] H. Adoni and H. Nossek, "The New Media Consumers: Media Convergence And The Displacement Effect,” Commun. Eur. J. Commun. Res., vol. 29, no. 3, pp. 399-400, 2004.

[16] S. McPhillips and O. Merlo, "Media convergence and the evolving media business model: an overview and strategic opportunities," Mark. Rev., vol. 8, no. 3, pp. 237-253, Sep. 2008, doi: $10.1362 / 146934708 \times 337663$.

[17] C. E. Helfat and R. S. Raubitschek, "Dynamic and integrative capabilities for profiting from innovation in digital platform-based ecosystems," Res. Policy, vol. 47, no. 8, pp. 1391-1399, Oct. 2018, doi: 10.1016/j.respol.2018.01.019.

[18] T. Quandt and S. Jane, City Research Online City , University of London Institutional Repository. New York: Routledge, 2009.

[19] C. Peil and S. Sparviero, "Media Convergence and Deconvergence," Media Converg. Deconvergence, pp. 3-30, 2017, doi: 10.1007/978-3-319-51289-1.

[20] E. Ytreberg, "Extended liveness and eventfulness in multi-platform reality formats," New Media Soc., vol. 11, no. 4, pp. 467-485, Jun. 2009, doi: 10.1177/14614444809102955.

[21] L. Mikos, "Digital media platforms and the use of TV content: Binge-watching and video-ondemand in Germany," Media Commun., vol. 4, no. 3A, pp. 154-161, Jul. 2016, doi: 10.17645/mac.v4i3.542. 